\title{
Access and utilisation of social and health services as a social determinant of health: the case of undocumented Latin American immigrant women working in Lleida (Catalonia, Spain)
}

\author{
Montserrat Gea-Sánchez RN MSN PhD ${ }^{1,2}$, Denise Gastaldo BScN MA PhD ${ }^{3}$, Fidel Molina-Luque BSc PhD ${ }^{4}$ and \\ Laura Otero-García RN MA PhD ${ }^{1,5}$ \\ ${ }^{1}$ Nursing Department, GESEC, Lleida University, Spain, ${ }^{2}$ Health Care Research Group (GRECS), IRB Lleida, Spain, \\ ${ }^{3}$ Lawrence S. Bloomberg Faculty of Nursing, University of Toronto, Canada, ${ }^{4}$ Geography and Sociology Department, \\ GESEC, Lleida University, Spain and ${ }^{5}$ National School of Public Health, Institute of Health Carlos III, Spain
}

Accepted for publication 23 November 2015

\section{Correspondence Montserrat Gea-Sánchez Carrer Rovira Roure 44 25198 Lleida, Spain E-mail: montse.gea@infermeria. udl.cat}

\section{What is known about this topic}

- Although Spain offered national social and healthcare systems based on universal access, immigrants underused them.

- Migrant workers are disproportionally affected by and exposed to risks in the workplace.

- Research has shown that language, fear of deportation and being a 'newcomer' constitute barriers to access and utilisation of social and healthcare systems.

\section{What this paper adds}

- The main barrier to access and use of social and healthcare systems in the case of undocumented Latin American women are their working conditions, which are linked to their lack of legal status.

- Living in a rural area facilitates registering for a health card with local authorities and accessing the healthcare system.

- Gender stereotypes and lack of legal status legitimise, naturalise and perpetuate precarious employment among undocumented Latin American women.

\begin{abstract}
Although Spain has social and healthcare systems based on universal coverage, little is known about how undocumented immigrant women access and utilise them. This is particularly true in the case of Latin Americans who are overrepresented in the informal labour market, taking on traditionally female roles of caregivers and cleaners in private homes. This study describes access and utilisation of social and healthcare services by undocumented Latin American women working and living in rural and urban areas, and the barriers these women may face. An exploratory qualitative study was designed with 12 in-depth interviews with Latin American women living and working in three different settings: an urban city, a rural city and rural villages in the Pyrenees. Interviews were recorded, transcribed and analysed, yielding four key themes: health is a tool for work which worsens due to precarious working conditions; lack of legal status traps Latin American women in precarious jobs; lack of access to and use of social services; and limited access to and use of healthcare services. While residing and working in different areas of the province impacted the utilisation of services, working conditions was the main barrier experienced by the participants. In conclusion, decent working conditions are the key to ensuring undocumented immigrant women's right to social and healthcare. To create a pathway to immigrant women's health promotion, the 'trap of illegality' should be challenged and the impact of being considered 'illegal' should be considered as a social determinant of health, even where the right to access services is legal.
\end{abstract}

Keywords: access to healthcare, employment, gender and inequality, inequalities in health and healthcare, migrants, utilisation 


\section{Introduction}

The IOM (2011) estimates that there are 214 million international migrant workers around the world. Since the United Nations National Assembly proclaimed healthcare as a human right in 1966, all countries are supposed to provide equal access to healthcare services for their population (Schoevers et al. 2010). However, specific legislation and regulations make access to healthcare for immigrants problematic in many countries (Devillanova 2008, Rousseau et al. 2008, Ravinetto et al.2009, Gastaldo \& Magalhaes 2010, Ruiz-Casares et al. 2010, Galarneau 2011, Sebo et al. 2011).

European policies are ambiguous in this regard. While restrictive immigration policies are enforced, criminalising the arrival, stay and employment of undocumented workers (Thomsen 2012), in 2011 the European Parliament adopted a resolution to reduce health inequalities in the European Union, calling on member states to tackle inequalities in access to healthcare for undocumented migrants (European Parliament resolution 2010/2089(INI)) following pressure from a petition of over 3 million healthcare professionals.

Evidence has shown that migrant workers are disproportionally affected by and exposed to risks in the workplace, and this is particularly true in the case of undocumented migrants who are usually employed in '3-D' jobs ('dangerous, dirty and degrading') in under-regulated sectors, such as domestic and agricultural work (Magalhaes et al. 2010, Benach et al. 2011, Vives et al. 2011, Gastaldo et al. 2012). The European Parliament's Committee on Employment and Social Affairs (2011) pointed out that the situation of domestic workers, many of whom are immigrant women, is particularly difficult. Many of them are impacted by physical and psychosocial problems, but data about their situation are minimal.

Although Spain has a national healthcare system model based on universal access, restrictive migratory policies have been adopted in response to European Union pressure and as governmental reaction to the post-2008 economic crisis. Until 2012, the Organic Law 4/2000 on rights and freedom of foreigners in Spain (Ley Orgánica 4/2000) acknowledged the right for immigrants who were registered in the municipal census to obtain a health service card and assistance regardless of their status. However, some studies have shown that fear of deportation, being a 'newcomer', language barriers and other problems could be obstacles for non-status migrants to access healthcare (Rousseau et al. 2008, Cohen 2009). In order to make visible this phenomenon, the aim of this study was to describe how undocumented Latin American women working and living in the various regions of the province of Lleida access and utilise social and healthcare services, and describe the barriers they faced.

\section{Characteristics of immigration to Spain}

In the 21st century, immigration to Spain has been characterised by rapid growth in and concentration of immigrants. In one decade, Spain acquired the second highest number of foreign residents in Europe, only surpassed by Germany. In addition, immigrants are concentrated in particular regions of the country. For instance, Catalonia is the autonomous community with the largest immigrant population $(21 \%$ of the total) with over a million people (Càtedra Repsol de Competitivitat i Desenvolupament Regional 2013).

This concentration responds mainly to opportunities in the labour market, which clearly becomes a labour stratification mechanism according to nationality, gender and area of activity, resulting in an overrepresentation of immigrants in agricultural and domestic employment (Moreno \& Bruquetas 2011). Regarding the latter sector, Latin American women now take on the role of caregivers and home cleaners, which coincide with the increased incorporation of Spanish women into the labour market (Bover et al. 2011).

\section{Access and utilisation of health and social services by the immigrant population in Spain}

Unlike most European countries, Spain granted undocumented workers access to social and health services between the years 2000 and 2012; access to a health card was conditional to registration in the municipal census, a fairly simple process in many cities. However, non-governmental organizations (NGOs) reported that there were informal barriers that prevented access to services (WHO 2010, Doctors of the World 2013).

Most studies in scientific literature that focus on access and utilisation of health services by the immigrant population in Spain, show a lesser utilisation of services such as hospital emergency services, primary healthcare and pharmaceutical expenses, compared to the local population (Soler-González et al. 2008, Hernando et al. 2009, Regidor et al. 2009, Ben Cheikh et al. 2011). However, these studies do not offer disaggregated data according to immigration status.

Although it is true that the immigrant population is young and, as a consequence is expected to enjoy better health, there is evidence showing that their 
(physical and mental) health status worsens once in the host country, mainly due to the characteristics and demands of their labour activities (Borrell et al. 2008, García \& Montuenga 2009, Aerny Perreten et al. 2010, Benach et al. 2011, Casado-Mejía et al. 2012).

With regard to social services, the situation is worse. Given immigrants' low and unstable income and their limited social and family networks, it would be expected they would utilise many social services. However, the data provided by Moreno and Bruquetas (2011) show that from the total number of social services interventions in Spain in 2008, only $6.85 \%$ occurred in the immigrant population. The latest data by the Ministry (MSPSI (España) 2012), corresponding to 2009, reveal that $86.31 \%$ of social services users are Spanish citizens.

\section{Conceptual framework}

Globalisation has intensified migratory movements which have been accompanied by a feminisation of labour, including more women getting better paid jobs who in turn need other women to perform caregiving and domestic work, given men's limited participation in unpaid domestic work in most societies (Bacon 2008, Standing 2011). These jobs are performed by the new precariat - a class of mobile, cheap migrant workers who have minimal rights and social protection (Standing 2011, Gastaldo et al. 2013).

In the current nation-state political spectrum, status may vary from full citizen to illegal alien. These socio-political actors establish different economic arrangements in the public and private arenas, but those who lack legal status or those who have their status changed over time are the ones whose social determinants of health are heavily impacted by these circumstances (Gastaldo et al. 2013). van Schendel and Abraham (2005) and later Thomsen (2012) developed a model that illustrates not only the dynamic nature of legal status but also reveals how ethical values shared by the citizens of host nations, socially accepted practices and government policy making all play a role in creating inclusion or exclusion of immigrant workers.

According to this model, the concept of compliance can help us to understand how immigrant workers are situated in different social locations depending on whether they fully, partially or do not comply with host nations laws regarding residence and work.

While those who are legal immigrants have their status approved by state laws, those who lack legal status may be socially legitimised and, as a consequence, can have variable social positions, depending on the values of the community and society in which they reside. For instance, some citizens consider any form of work as noble and licit, despite not being legal (van Schendel \& Abraham 2005, Thomsen 2012).

These shared values on work and migration are then intersected by ideas about gender, race and nationality, creating a complex post-colonial set of relations that legitimises or naturalises precarious working conditions or access to healthcare as acceptable for some groups, but not for others.

This variability results in a field of tension when what is considered legal comes into confrontation with what is accepted as licit, giving place to situations of civil disobedience, such as those experienced in Catalonia during 2012, when the Spanish state passed the Royal Decree Law 16/2012 establishing urgent measures to improve the quality and safety and ensure the sustainability of the national healthcare system (Real Decreto-ley 16/2012, de 20 de abril), which explicitly excluded undocumented immigrants from accessing healthcare. However, in Catalonia, undocumented migrants were allowed to retain their rights preceding the introduction of the aforementioned law (Llei orgànica 6/2006, de 19 de juliol, CatSalut 2012, Recurso de inconstitucionalidad no. 414-2013).

\section{Methodology}

This study was conducted in the province of Lleida, which is part of the Catalan Autonomous Community (Spain) and the second largest province in Spain. It has the lowest population density in Catalonia (36.4 in $\mathrm{h} / \mathrm{km}^{2}$ ). In Lleida, $54.68 \%$ of the population lives in rural areas (municipalities with less than 10,000 inhabitants). Of those, $23.64 \%$ of the population live in municipalities with less than 2000 inhabitants, and $31.04 \%$ in municipalities with between 2001 and 10,000 inhabitants (IDESCAT 2013). Lleida is one of the top 10 Spanish provinces with the highest immigrant population per total population (18.24\%, higher than Madrid and Barcelona), largely because of the jobs created by agricultural and farming industries (Figure 1).

An exploratory qualitative study (Hesse-Biber 2006) using in-depth interviews with 12 undocumented Latin American immigrant women living and working in three different settings was conducted: an urban city (more than 100,000 inhabitants), a rural city (9000 to 11,000 inhabitants) and rural villages of the Pyrenees (less than 1000 inhabitants). Given the exploratory nature of this study, different settings were chosen to examine whether place of residence was also a factor to be considered when studying 


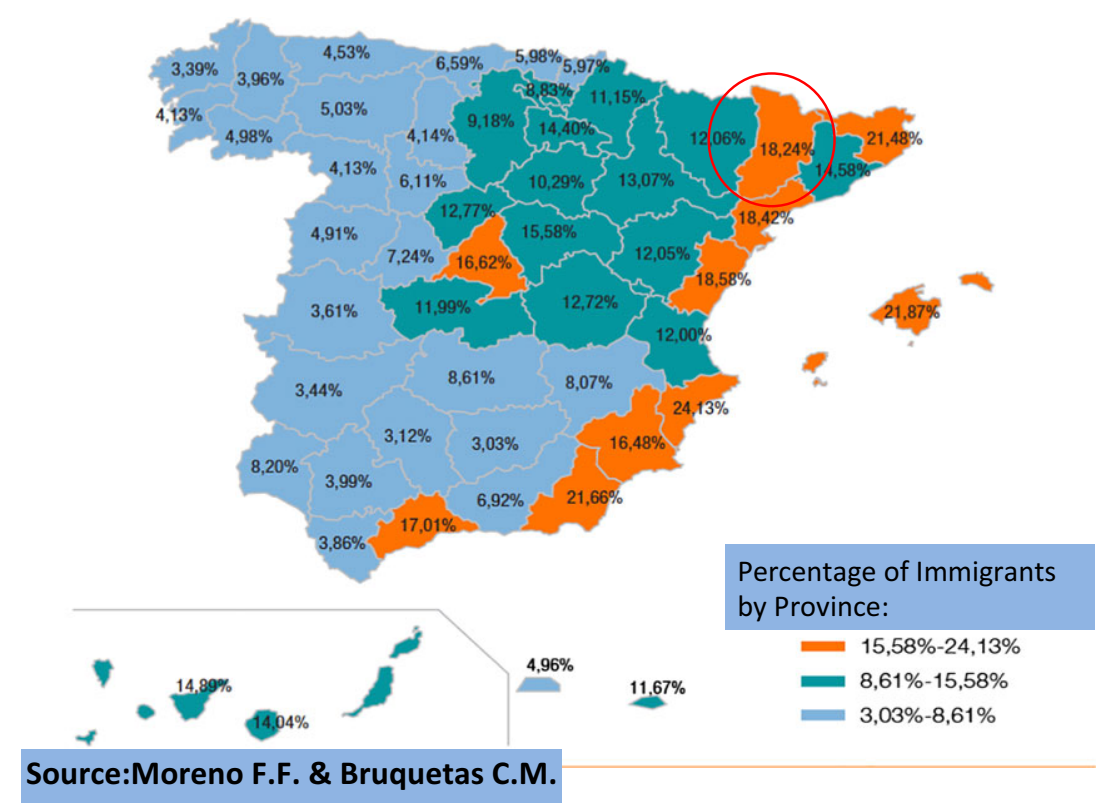

Figure 1 Percentage of immigrants by province in Spain.

access and utilisation of services for undocumented immigrant women.

An immigrant woman working as a Cultural Mediator $(\mathrm{CM})$, who was previously undocumented herself, recruited one urban and one rural undocumented Latin American woman. The recruitment proceeded through a snowball technique. Interviews were conducted in participants' homes for approximately 90 minutes by the interviewer and the $\mathrm{CM}$ in a dialogical manner to make participants feel comfortable. Institutional settings were avoided because they could inhibit an open conversation about social and healthcare services. The participants' age ranged from 19 to 52 years old, the average educational level was high school, and they had been living in Spain between 2 and 13 years, some never had legal status, while others lost it (see Table 1). The fieldwork was carried out by the first author (MG) between September and December 2011. The interview guide included topics on migratory process, legal status, working conditions, perception of their own health and access to and use of health and social services. The interviews were recorded and transcribed and field notes were incorporated into the verbatim. After preliminary analysis, the first author (MG) identified considerable repetition of data and considered that saturation on the key issues of the study was achieved. Data analysis consisted of several procedures (Silverman 2013) including: first, line by line coding of all data; second, grouping of ideas emerging from this inductive analysis under subcategories; third, refinement of the coding system and subcategories; fourth, identification of central themes presented in our findings; and fifth, verification of the analysis by a researcher (LO) who did not participate in data collection.

Prior to the interview, participants were asked for oral informed consent and were given written information about study objectives, confidentiality and recording of interviews. The participants' names, their cities/villages and the services they have used were omitted or replaced by pseudonyms in order to preserve confidentiality; this was especially important for participants residing in rural villages.

\section{Findings}

Four main themes emerged describing access and utilisation of social and healthcare services and the barriers that Latin American women faced: health is a tool for work which worsens due to precarious working conditions; lack of legal status traps Latin American women in precarious jobs; lack of access to and use of social services; and limited access to and use of healthcare services.

\section{Health is a tool for work which worsens due to precarious working conditions}

All participants considered that having good health equates to having a stable job. They had certain difficulty talking about health in abstract terms. Having 
Table 1 Profile of participants

\begin{tabular}{|c|c|c|c|c|c|c|c|}
\hline Pseudonym & Age & Nationality & Education & Residence & $\begin{array}{l}\text { Years in } \\
\text { Spain }\end{array}$ & Jobs & Dependents \\
\hline Denise & 19 & Dominican & High School & Urban city & 4 & $\begin{array}{l}\text { Domestic and Bar } \\
\text { Cleaning (on demand) }\end{array}$ & Yes \\
\hline Maribel & 20 & Brazilian & Primary & Rural Village & 2 & $\begin{array}{l}\text { Domestic cleaning } \\
\text { (on demand) }\end{array}$ & No \\
\hline Laura & 22 & Brazilian & Primary & Rural Village & 5 & $\begin{array}{l}\text { Domestic and Hotel } \\
\text { Cleaning (on demand) }\end{array}$ & No \\
\hline Santiaga & 28 & Bolivian & $\begin{array}{l}\text { University } \\
\text { (unfinished) }\end{array}$ & Urban city & 6.5 & $\begin{array}{l}\text { Domestic cleaning } \\
\text { (on demand) }\end{array}$ & Yes \\
\hline Andrea & 29 & Brazilian & $\begin{array}{l}\text { University } \\
\text { (unfinished) }\end{array}$ & Rural Village & 3.5 & $\begin{array}{l}\text { Domestic cleaning } \\
\text { (on demand) }\end{array}$ & Yes \\
\hline Fidela & 29 & Brazilian & Primary & Rural Village & 2 & $\begin{array}{l}\text { Domestic and Hotel } \\
\text { Cleaning (on demand) }\end{array}$ & Yes \\
\hline Carmen & 32 & Bolivian & Primary & Urban city & 6 & $\begin{array}{l}\text { Domestic cleaning } \\
\text { (on demand) }\end{array}$ & Yes \\
\hline Ana & 33 & Bolivian & High School & Urban city & 7 & $\begin{array}{l}\text { Caregiver and domestic } \\
\text { cleaning (on demand) }\end{array}$ & Yes \\
\hline María & 36 & Colombiana & Primary & Urban city & 13 & $\begin{array}{l}\text { Caregiver and domestic } \\
\text { cleaning (on demand) }\end{array}$ & Yes \\
\hline Miguela & 46 & Brazilian & Technical Diploma & Rural City & 1.5 & $\begin{array}{l}\text { Domestic and Hotel } \\
\text { Cleaning (on demand) }\end{array}$ & Yes \\
\hline Josefa & 50 & Chilean & Technical Diploma & Rural City & 8 & $\begin{array}{l}\text { Caregiver and domestic } \\
\text { cleaning (on demand) }\end{array}$ & No \\
\hline Juana & 52 & Chilean & Technical Diploma & Rural City & 5 & $\begin{array}{l}\text { Caregiver at hospital and } \\
\text { domestic cleaning }\end{array}$ & Yes \\
\hline
\end{tabular}

good health was described as a social concept. Health assures the ability to work and to obtain income to cater for the people participants are responsible for (children and/or parents), as explained below:

I feel healthier and better when I have a job, when I know I can provide for my daughters (...). I'm concerned about my health, because unless I work I cannot send anything to Bolivia for my daughters. (Ana, urban city)

(...) I came to earn money to pay for our children's studies. I had an accident and my health is now frail (...). I'm worried about what may happen, because I will not be able to work and send money to my children. (Santiaga, urban city)

Participants indicated a decrease in their health status after migration. In the case of immigrants living in villages, this loss is described in terms of physical health, while in the case of immigrants living in rural and urban cities, the deterioration affects both physical and mental health:

While I was living over there [country of origin] I never fell ill. Never. Now my hips are sore all the time. Always. (...) I never knew what it was to be depressive and here ... it happens all the time. (María, urban city)

This worsening health status is explained by the radicalisation of the precarious working conditions experienced by the participants. All of them began their immigration journey in Spain caring for seniors, having a stable wage, even though those who resided with their employers had several experiences of exploitation and did not want to ever go back into bonded labour (working and residing at the employers' property). Later, due to the effects of the economic recession or the death of their care recipients, participants moved into a combination of parttime jobs, cleaning private houses, restaurants or hotels or looking after children and elderly people. These jobs were characterised by unpredictable schedule, income insecurity and lack of benefits derived from stable work, such as the right to in-service training or measures for reducing risks in the workplace:

I'm looking after a couple of elderly people in the hospital [rural city]. I go every day to feed them and give them their medication (...) on top of this job, I clean houses. This morning I have worked 5 hours, but every day is different. I also did work for the Town Council of [Rural Village]. (Juana, rural city)

When something needs to be cleaned more thoroughly ... I use 'salfuman' [caustic soda] or a fat remover that is very strong [...] Products are the difficult bit of cleaning [...] Nobody has taught me how to clean: women seem to be born knowing how to clean. (...) I don't use anything to protect myself. (Andrea, rural village) 
The participants revealed that public and private employers are alike, and the immigrant workers themselves assume caring and cleaning work as gendered activities that are intrinsically known by women and undervalued socially and economically.

\section{Lack of legal status traps Latin American women in precarious jobs}

As suggested above, to be healthy is to be able to perform a job and participants tie the possibility of finding a stable job to their legal status. Participants described having lost many job opportunities because they were undocumented. They felt that a vicious circle is generated, as being undocumented they cannot get jobs with a legal contract and social benefits, and thus they are trapped in the underground economy, where jobs have no labour rights and workers live in fear of being discovered and penalised.

What worries me is my health and my papers [legal permit] (...) because my first application for residency has been rejected (...). I had to turn down many job offers because I didn't have the papers. (Juana, rural city)

I had problems in my job because I had no papers. I was working in a hotel; I had to hide all the time. Always running away from someone or another: this is slavery. (Miguela, rural city)

Some participants have always lived in an irregular situation, while others lost their legal status as a consequence of the economic recession:

When I lost my papers ... everything went awry (...) I would like to go back to doing what I was doing when I had my papers: catering. I love being a waitress. But now they only call me for fairs (...). (María, urban city)

Participants described having lost many opportunities for employment because they are undocumented, and also accepting jobs without negotiating working hours or salary:

I'm getting by with what I have. If I had papers I would find better and steadier jobs. (...) Yes, I work on an hourly basis, you know. In the hotel, (...) sometimes I do houses. It varies, as it's on an hourly basis, the day that there is work. (Laura, rural village)

It should be noted that women with children were particularly vulnerable to situations of oppression, abuse and racism by their employers or care recipients.

...because in some jobs..., in one there was some racism (...), they humiliated me, well ... I needed money to send to my children. The kids [care recipients] used to beat me (...). In Madrid they called me 'fucking immigrant' in one house (...) the elderly for whom I worked. (Santiaga, urban city)

In spite of more work opportunities and wage stability, situations of abuse arose much more often in bonded labour. The main problems were sleep deprivation, lack of food and no free time to rest:

(...) the man had dementia (...). I slept in a room next to the man's and he knocked on the wall every two hours for attention. That work was 24 hours a day during 3 years. (...) They told me they would legalise my papers, but they never did. (Josefa, rural city)

As reported above, employers also used the promise of legal permits in order to retain women in precarious jobs.

\section{Lack of access to and use of social services}

Latin American women living in rural settings verbalised they had never tried to access social services, while the rest of participants did try, but could not use these services because of their legal status. Participants living in cities reported that the lack of legal status not only shaped government institutional policies but also NGOs because they too just provided social services for documented immigrants:

I can't get unemployment benefit, and can't go to the social worker all the time. She won't give me anything. (María, urban city)

(...) and from social services I went to the Red Cross. I went many times. They said they'd call me, but they never did. I went to Cáritas in [rural city] and the same thing happened. The girls at the Red Cross said if I had papers I would be working already. But I don't have them, and she said she couldn't do anything, that they had their hands tied. (Miguela, rural city)

Additionally, participants who have tried to use social services expressed their frustration and channelled it by blaming social workers for the decisions made, failing to see that social workers were constrained by governmental or institutional policies:

She could have helped me, at least with the food for the house or something ... she helped a lot of people, but not me, she said she couldn't. (Denise, urban city)

Of all participants interviewed, only one was able to use social services, in particular to get additional food, but this may have been because of her husband and sons' legal status.

We had applied for supplementary economic assistance that the social worker had told us about. She said she could present our case because we're a large family and my husband and my children have papers and he's unemployed. (...) 
They give you 3 packs of milk and something else, but this is not enough (...) I went to the Red Cross because the food they gave us was insufficient; in the food bank they give you more rice and flour. But there's not even the basics, I mean, the kids want yogurt, sugar (...) basic things. I went [to the Red Cross] and she said the social worker had to refer me there, but the social worker well ... she can't or she says no. (Carmen, urban city)

Participants did not understand the rules that were being applied to different cases and were excluded from any form of social services.

\section{Limited access to and use of healthcare services}

The Latin American women interviewed indicated differences in registering and accessing the healthcare system according to place of residence. Participants who lived in rural settings described an easy process to obtain their health card, while those who lived in larger cities faced difficulties both to get their health card and in accessing health services. Lack of knowledge about how to register was not a barrier.

The barriers described included employers and landlords who refused to sign a contract to avoid paying taxes (and therefore women could not demonstrate their residence in order to obtain a health card) and administrative staff in hospitals, who 'administratively screen' emergency clients:

In Barcelona I lived in a room, and the owner of the apartment didn't want to register me, therefore I could never have a card. I only managed to register and get a health card here, in [rural village] (...) sometimes I have been to emergency, but they asked me for my card, on some occasions they didn't assist me. (Laura, rural village, talking about her previous experience when living in Barcelona)

However, being a cardholder and living in a rural village did not guarantee access to health services either. Some participants could not afford the time or cost of travelling between the rural villages of the Pyrenees and the referral hospital (3-hour journey by public transport in good weather conditions):

(...) at the beginning I was worried because it was hard to get an appointment and go to [urban city] to get tests done, because we couldn't get them done here. (Andrea, rural village)

In spite of the importance of the geographical area, the main barrier to the utilisation of healthcare reported by participants was in relation to precarious working conditions and abusive employers. A single day off work represented losing a day's pay, and also carried the threat of being fired. Labour precariousness was more extreme again in the case of bonded labourers, as their employers sometimes even denied them their right to access primary healthcare services, and made them work while sick:

(...) I was off for a day, one Sunday, every fortnight and if I wanted to go to the doctor, the lady [the boss] said it had to be on that day. My back was very sore... (Josefa, rural city)

Taking into account access barriers, the use of healthcare services in the case of participants who lived in rural villages was basically limited to the local primary healthcare centre. A few cases though were referred to the provincial hospital, when deemed necessary. The reasons for consultations were limited mainly to acute physical problems (e.g. stomach haemorrhage, back pain, etc.) and reproductive services and prenatal care:

Once I went to the health centre because my face became swollen. (...) I was supposed to have some allergy tests done [at referral hospital], but I never went back. (Maribel, rural village)

Participants who lived in cities used the health system for physical and mental health problems. For the latter, they were not referred from primary healthcare to specialised centres:

(...) well, I have become very nervous. I have depression and anxiety problems. Before the baby, I was taking pills that the family doctor gave me, but when I got pregnant I gave them up. (Carmen, urban city)

Regardless of the geographical area, as Maribel and Carmen reported, once the acute stage of the disease is over, participants had limited follow-up and adherence to treatment. Once they were able to work again, they went back into their labour activities.

\section{Discussion}

In this study, we have identified that for undocumented Latin American women living and working in the province of Lleida, irrespective of region, the main barrier to accessing social and health services is precarious working conditions in care-giving and cleaning occupations. The intersection of several social determinants of health, in particular precarious working conditions associated with lack of status, nationality/race and gender, places them in a vulnerable situation that is detrimental to their physical, mental and social health.

Over the last decade, scientific literature exposed immigrants' poor quality of life as well as physical and mental suffering as consequences of their precarious work in Spain (Borrell et al. 2008, García \& Mon- 
tuenga 2009, Ahonen et al. 2010, Sanchón-Macias et al. 2013). However, since the economic recession started, poor employment conditions and fear of unemployment have increased presenteeism (working while sick) and discouraged health-seeking behaviours (Galon et al. 2014, Ronda Pérez et al. 2015). The experience of other immigrants corroborates the description provided by our participants, who selfassessed their health as 'able to work' - their sole indicator of good health.

In the informal labour market of cleaning and care-giving, occupational precariousness is socially reproduced because these jobs traditionally do not allow immigrant women to acquire legal status (Hondagneu-Sotelo 2001, Briones Vozmediano et al. 2014). In the context of the Spanish recession, study participants lost full-time jobs and were left with multiple part-time jobs, which according to Thomsen's model (2012), moved them from a position of 'compliance' or 'semi-compliance' to 'non-compliance', and therefore, 'trapped in illegality' and vulnerable to exploitation (Miklavcic 2011).

The fact that they were women and 'Latinas' legitimised labour segmentation and naturalised domestic activities as their occupation (Fernández \& Ortega 2007, Porthé et al. 2010). The old colonial order still provides justification for exploitative relations, especially when nationality and race are seen as analogous to subalternity (Hondagneu-Sotelo 2001, Federici 2010, Bianchi Pernasilici 2014). Even though study participants seldom referred directly to racism, but rather spoke in generic terms about humiliation and discrimination, conceptually, they were talking about the colonial logic of servilism, which is supported by racism and sexism (Federici 2010, Agudelo Suárez et al. 2011, Bianchi Pernasilici 2014). It is paradoxical that Spanish women's liberation from caregiving and cleaning duties have been achieved in part at the expense of Third World migrant women's rights and health, most of them their former colonial subjects (Domínguez \& Guerra 2006, Ahonen et al. 2010, Briones Vozmediano et al. 2014).

In this context of neo-colonialism and non-compliance, trapped in illegality, access and utilisation of social and health services was very limited. However, at the time data were being collected, Spain (together with other European countries, such as Italy and Portugal) was held as an exemplar of good practice, with a legal framework that acknowledged full rights for undocumented immigrants to access social and healthcare services (Dias et al. 2011, Rechel et al. 2011). Our participants' reveal that access did not happen in the intended manner, that is: 'providing the right services at the right time in the right place'
(Rogers et al. 1999). Considering this definition, from resource allocation to actual service utilisation, there was a clear service failure for undocumented Latin American women (Tanahashi 1978).

In the case of social services, the principles of social protection were breached when undocumented workers were denied access and coverage at a time of especial vulnerability. Data provided by the Colectivo IOÉ (2012) revealed that half of all foreign workers fired in the last few years had no right to welfare protection, and consequently poverty and exclusion rates have dramatically increased for this group (Otazu Urra 2012).

The current policies of both the national and the autonomous communities transfer social assistance responsibility to NGOs which have been overwhelmed in recent years by requests for assistance with an increase of $170 \%$, going back to the levels of the 1980s in the form of soup kitchens (Cáritas Española 2012). In the particular case of this study, NGOs did not provide any assistance to participants.

Regarding healthcare services, geographic location plays a role in access to services. In rural villages, for instance, there seem to be fewer administrative barriers to get a health card, and better information is provided in comparison to cities. In scientific literature, rural and remote locations have been habitually considered as generators of inequity for healthcare access and utilisation (Canadian Population Health Initiative 2006, Bourke et al. 2012). Conversely, in the case of the undocumented women studied, it became a facilitator, as participants were able to bypass some formal barriers, such as census registration. However, geographic location remained a generator of inequity when travel to a hospital was needed, given the cost of travel and lost wages.

Social and healthcare needs also differed in some aspects according to the geographic location. For instance, undocumented women who lived and worked in cities had more needs related to mental health, such as anxiety disorders and depression. Yet, all participants limited their consultations to acute problems with the aim of keeping active, or to reproductive health issues. Prevention services, such as early detection of breast or cervical cancer, were not used, although many participants met inclusion criteria (Generalitat de Catalunya 2006a,b).

Therefore, the myth that exists in many countries that access to healthcare implies a massive utilisation of services by immigrants or the perception supported by some studies that immigrants 'abuse or misuse the healthcare system' is not supported by our findings (Solé Auró et al. 2010, Moreno \& Bruquetas 2011). 


\section{Conclusions}

In this study, the undocumented women in the province of Lleida described barriers to access and use social and healthcare services although, at the time, Spain had a legal provision to provide healthcare for everyone regardless of legal status. In order to guarantee a real path leading to health promotion and health equity for immigrant workers, workers should be offered dignified working and living conditions. Given the detrimental impact of undocumentedness, the first step would be to provide immigrant workers status that places them in a fully legal and licit space, to break the 'illegality trap' by considering an individual's status as a social determinant of health.

However, as our results reveal, such movement towards legal status through public policy is insufficient. Social values also determine what is licit, and where discrimination occurs in each society. If employers, care recipients, social and healthcare professionals, or the population as a whole do not believe immigrants should access social and healthcare, even in a province where the right is legal, it may not be enacted.

\section{Acknowledgements}

The authors especially thank the participants who kindly agreed to be interviewed and Rachida Amrouch who acted as ICM. The authors also acknowledge the feedback provided by Joan Ganau (Universitat de Lleida, Spain), Colectivo IOÉ, Jessica Schultz (University of Bergen, Norway) and Andreu Bover-Bover (Universitat de les Illes Balears, Spain). This research was supported by Instituto de Salud Carlos III, Ministerio de Innovación, Economía y Competitividad, No. Registro 4669/RG943974, CEJEM at University of Lleida and Lleida's Institute of Biomedical Research.

\section{References}

Aerny Perreten N., Ramasco G.M., Cruz Maceín J.L., Rodríguez R.C., Garabato G.S. \& Rodríguez L.A. (2010) La salud y sus determinantes en la población inmigrante de la Comunidad de Madrid. Gaceta Sanitaria/S.E.S.P.A.S. 24 (2), 136-144.

Agudelo Suárez A.A., Ronda P.E., Gil G.D. et al. (2011) The effect of perceived discrimination on the health of immigrant workers in Spain. BMC Public Health 11, 652.

Ahonen E.Q., López-Jacob M.J., Vázquez M.L. et al. (2010) Invisible work, unseen hazards: the health of women immigrant household service workers in Spain. American Journal of Industrial Medicine 53 (4), 405-416.
Bacon D. (2008) Illegal People: How Globalization Creates Migration and Criminalizes Immigrants. Bacon Press, Boston.

Ben Cheikh W., Abad J.M., Arribas F., Andrés E. \& Rabanaque M.J. (2011) Utilización de los hospitales públicos por la población extranjera en Aragón (2004-2007). Gaceta Sanitaria/S.E.S.P.A.S 25 (4), 314-321.

Benach J., Muntaner C., Delclos C., Menéndez M. \& Ronquillo C. (2011) Migration and «low-skilled» workers in destination countries. PLoS Medicine 8 (6), e1001043.

Bianchi Pernasilici G.M. (2014) Migraciones y trabajo doméstico de cuidados. El caso de la población andina en el Gran Bilbao. PhD Thesis. Universidad del País Vasco, Bilbao.

Borrell C., Muntaner C., Solà J., Artazcoz L., Puigpinós R., Benach J. \& Noh S. (2008) Immigration and self-reported health status by social class and gender: the importance of material deprivation, work organisation and household labour. Journal of Epidemiology and Community Health $\mathbf{6 2}$ (5), e7.

Bourke L., Humphreys J.S., Wakerman J. \& Taylor J. (2012) Understanding rural and remote health: a framework for analysis in Australia. Health E Place 18 (3), 496-503.

Bover A., Gastaldo D., Meyer D. et al. (2011) Economic crisis, austerity discourses and caregiving: how to remain relevant through engagement and social justice. Nursing Inquiry 18 (3), 188-190.

Briones Vozmediano E., Agudelo Suárez A.A., López Jacob M.J., Vives C.C., Ballester L.F. \& Ronda P.E. (2014) Percepción de las trabajadoras inmigrantes del servicio doméstico sobre los efectos de la regulación del sector en España. Gaceta Sanitaria/S.E.S.P.A.S 28 (2), 109-115.

Canadian Population Health Initiative (2006) How Healthy Are Rural Canadians? An Assessment of Their Health Status and Health Determinants. Canadian Institute for Health Information, Ottawa, Ontario.

Cáritas Española (2012) VII Informe del Observatorio de la Realidad Social: de la coyuntura a la estructura: los efectos permanentes de la crisis. Cáritas, Madrid.

Casado-Mejía R., Ruiz-Arias E. \& Solano-Parés A. (2012) El cuidado familiar prestado por mujeres inmigrantes y su repercusión en la calidad del cuidado y en la salud. Gaceta Sanitaria/S.E.S.P.A.S 26 (6), 547-553.

Catalunya (2006) Llei orgànica 6/2006, de 19 de juliol, de reforma de l'Estatut d'autonomia de Catalunya. DOGC de 19 de Juliol de 4680, 31875-31936.

Càtedra Repsol de Competitivitat i Desenvolupament Regional (2013) La població estrangera a Catalunya. Apunts de Prospectiva Territorial maig (2), 1-7.

CatSalut (2012) Instrucció 10/2012 de 30 d'agost d'Accés a l'assistència sanitària de cobertura pública del CatSalut als ciutadans estrangers empadronats a Catalunya que no tenen la condició d'assegurats o beneficiaris del Sistema Nacional de Salut. Available at: http://scientiasalut.gencat.cat/bitstream/handle/11351/1319/catsalut_instruccio_10_2012. pdf?sequence $=1$ (accessed on 15/7/2014).

Cohen M.H. (2009) Commentary: undocumented women: pushed from poverty and conflict, pulled into unjust disparity. Journal of Public Health Policy 30 (4), 423-426.

Colectivo IOÉ (2012) Impactos de la crisis sobre la población inmigrante. Colectivo IOÉ, Madrid.

Devillanova C. (2008) Social networks, information and health care utilization: evidence from undocumented immigrants in Milan. Journal of Health Economics 27 (2), 265-286. 
Dias S., Gama A., Cortes M. \& de Sousa B. (2011) Healthcare-seeking patterns among immigrants in Portugal. Health and Social Care in the Community 19, 514-521.

Doctors of the World (2013) Access to Healthcare in Europe in Times of Crisis and Rising Xenophobia: An Overview of the Situation of People Excluded from Healthcare Systems. Doctors of the World, Paris.

Domínguez M.J. \& Guerra T.R. (2006) Domestic service and the labour market in Spain: a gender perspective on migration. Migracijske i Etničke Teme 22 (1-2), 95.

España (2000) Ley Orgánica 4/2000 sobre derechos y libertades de los extranjeros en España y su integración social.. BOE de 10 de Enero de 10 10, 1139-1150.

España (2012) Real Decreto-ley 16/2012, de 20 de abril, de medidas urgentes para garantizar la sostenibilidad del Sistema Nacional de Salud y mejorar la calidad y seguridad de sus prestaciones.. BOE de 24 de Abril de 98 (1), 31278-31312.

España X. (2013) Recurso de inconstitucionalidad no. 4142013, contra los artículos 1.Uno, Dos y Tres; 4.Uno, Cuatro, Cinco y Catorce; 6, apartados 2 y 3; 8.Dos; 10.Cuatro y disposición final sexta.Uno del Real Decreto-ley 16/ 2012, de 20 de abril, de medidas urgentes para garantizar la sostenibilidad del Sistema Nacional de Salud y mejorar la calidad y seguridad de sus prestaciones. BOE de 22 de Febrero de 46, 14860.

European Parliament (2011) European parliament resolution of 8 March 2011 on reducing health inequalities in the EU (2010/2089(INI)). Available at: http://www.europarl.europa.eu $/$ sides $/$ getDoc.do?type=REPORT\&reference=A72011-0032\&language $=$ EN (accessed on 2/7/2014).

Federici S. (2010) Calibán y la bruja: mujeres, cuerpo y aсumulación primitiva. Traficantes de Sueños, Madrid.

Fernández C. \& Ortega C. (2007) Labor market assimilation of immigrants in Spain: employment at the expense of bad job-matches? Spanish Economic Review 10 (2), 83-107.

Galarneau C. (2011) Still missing: undocumented immigrants in health care reform. Journal of Health Care for the Poor and Underserved 22 (2), 422-428.

Galon T., Briones Vozmediano E., Agudelo Suárez A.A., Felt E.B., Benavides F.G. \& Ronda E. (2014) Understanding sickness presenteeism through the experience of immigrant workers in a context of economic crisis. American Journal of Industrial Medicine 57 (8), 950-959.

García M.I. \& Montuenga G.V. (2009) Causas de los accidentes de trabajo en España: análisis longitudinal con datos de panel. Gaceta Sanitaria/S.E.S.P.A.S 23 (3), $174-178$

Gastaldo D. \& Magalhaes L. (2010) International migration versus national health-care. Nursing Inquiry 17 (3), 185.

Gastaldo D., Carrasco C. \& Magalhães L. (2012) Entangled in a Web of Exploitation and Solidarity: Latin American Undocumented Workers in the Greater Toronto Area. Centre for Spanish Speaking Peoples (CSSP), Toronto.

Gastaldo D., Carrasco C. \& Magalhaes L. (2013) The creation of a mobile workforce: Latin American undocumented workers in the greater Toronto area. Latin American Encounters 1 (1), 18-32.

Generalitat de Catalunya (2006a) Programa de detecció precoç de càncer de mama. Available at: http://www20.gencat.cat/portal/site/cancer/menuitem.c55b6cfe04a239f796072d 10b0c0e1a0/?vgnextoid $=5 \mathrm{c} 2213 \mathrm{a} 323 \mathrm{~b} 73210 \mathrm{VgnVCM} 10000$ 00b0c1e0aRCRD\&vgnextchannel=5c2213a323b73210VgnVC
M1000000b0c1e0aRCRD\&newLang=es_ES (accessed on $15 / 7 / 2014)$.

Generalitat de Catalunya (2006b) Programa de detecció precoç de càncer de coll d'úter. Available at: http://www20.gencat.cat/portal/site/cancer/menuitem.c55b6cfe04a239f7960 72d10b0c0e1a0/?vgnextoid=7bc213a323b73210VgnVCM10 00000b0c1e0aRCRD\&vgnextchannel=7bc213a323b73210Vgn VCM1000000b0c1e0aRCRD\&newLang=ca_ES (accessed on $15 / 7 / 2014)$.

Hernando A.L., Palomar R.J., Márquez C.M. \& Monteagudo P.O. (2009) Impacto de la inmigración sobre la asistencia hospitalaria: frecuentación, casuística y repercusión económica. Gaceta Sanitaria/S.E.S.P.A.S. 23 (3), 208-215.

Hesse-Biber S.J. (2006) The Practice of Qualitative Research. Patricia Leavy, Sharlene Nagy Hesse-Biber.

Hondagneu-Sotelo P. (2001) Doméstica: Immigrant Workers Cleaning and Caring in the Shadows of Affluence. University of California Press, Berkeley.

IDESCAT (2013) Población. Por dimensión del municipio. Comarcas, ámbitos y provincias Anuario Estadístico de Cataluña, Institut d'Estadística de Catalunya, Barcelona.

IOM (2011) World Migration Report 2011: Communicating Effectively about Migration. International Organization for Migration, Geneva.

Magalhaes L., Carrasco C. \& Gastaldo D. (2010) Undocumented migrants in Canada: a scope literature review on health, access to services, and working conditions. Journal of Immigrant and Minority Health/Center for Minority Public Health 12 (1), 132-151.

Miklavcic A. (2011) Canada's non-status immigrants: negotiating access to health care and citizenship. Medical Anthropology 30 (5), 496-517.

Ministerio de sanidad política social e igualdad (España) (2012) Informe sobre los datos generales 2009 y avance 2010 del Sistema Integrado de Utilización de Servicios Sociales (SIUSS). SIUSS, Madrid.

Moreno F.F. \& Bruquetas C.M. (2011) Inmigración y estado de bienestar en España. Obra Social la Caixa, Barcelona.

Otazu Urra J.M. (2012) Las políticas sociales del estado del bienestar en españa: inmigración, discapacidad y exclusión social. In: V.J. Benito Gil, J.M. Canales Aliende \& M.E. Orjuela Ramírez (Eds) Estado del bienestar y politicas sociales: una aproximación a la situación española y colombiana, pp. 109-128. Club Universitario, Alicante.

Porthé V., Ahonen E., Vázquez M.L. et al. (2010) Extending a model of precarious employment: a qualitative study of immigrant workers in Spain. American Journal of Industrial Medicine 53 (4), 417-424.

Ravinetto R., Lodesani C., D’Alessandro U., De Filippi L. \& Pontiroli A. (2009) Access to health care for undocumented migrants in Italy. Lancet 373 (9681), 2111-2112.

Rechel B., Mladovsky P., Devillé W., Rijks B., Petrova-Benedict R. \& McKee M. (Eds) (2011) Migration and Health in the European Union. Open University Press, Maidenhead, Berkshire.

Regidor E., Sanz B., Pascual C., Lostao L., Sánchez E. \& Díaz Olalla J.M. (2009) La utilización de los servicios sanitarios por la población inmigrante en España. Gaceta Sanitaria/S.E.S.P.A.S 23 (Suppl. 1), 4-11.

Rogers A., Flowers J. \& Pencheon D. (1999) Improving access needs a whole systems approach. And will be important in averting crises in the millennium winter. BMJ (Clinical Research ed.) 319 (7214), 866-867. 
Ronda Pérez E., Briones Vozmediano E., Galon T., García A.M., Benavides F.G. \& Agudelo Suárez A.A. (2015) A qualitative exploration of the impact of the economic recession in Spain on working, living and health conditions: reflections based on immigrant workers' experiences. Health Expectations: An International Journal of Public Participation in Health Care and Health Policy [Epub ahead of print].

Rousseau C., ter Kuile S., Muňoz M., Nadeau L., Ouimet M.J., Kirmayer L. \& Crépeau F. (2008) Health care access for refugees and immigrants with precarious status: public health and human right challenges. Canadian Journal of Public Health 99 (4), 290-292.

Ruiz-Casares M., Rousseau C., Derluyn I., Watters C. \& Crépeau F. (2010) Right and access to healthcare for undocumented children: addressing the gap between international conventions and disparate implementations in North America and Europe. Social Science E Medicine (1982) 70 (2), 329-336.

Sanchón-Macias M.V., Prieto-Salceda D., Bover-Bover A. \& Gastaldo D. (2013) Relationship between subjective social status and perceived health among Latin American immigrant women. Revista Latino-Americana de Enfermagem 21 (6), 1353-1359.

van Schendel W. \& Abraham I. (2005) Illicit Flows and Criminal Things: States, Borders, and the Other Side of Globalization. Indiana University Press, Bloomington.

Schoevers M.A., Loeffen M.J., van den Muijsenbergh M.E. \& Lagro-Janssen A.L.M. (2010) Health care utilisation and problems in accessing health care of female undocumented immigrants in the Netherlands. International Journal of Public Health 55 (5), 421-428.

Sebo P., Jackson Y., Haller D.M., Gaspoz J.-M. \& Wolff H. (2011) Sexual and reproductive health behaviors of undocumented migrants in Geneva: a cross sectional study. Journal of Immigrant and Minority Health/Center for Minority Public Health 13 (3), 510-517.

Silverman D. (2013) Doing Qualitative Research: A Practical Handbook. Sage, Thousand Oaks, CA.

Solé Auró A., Mompart P.A., Brugulat G.P. \& Guillén E.M. (2010) Inmigración y uso de servicios sanitarios en tres zonas sanitarias de Cataluña. Revista Española de Economia de la Salud 9 (2), 81-91.

Soler-González J., Arnáiz C.S., Monné M.R., Gaya A.B., Magaz M.C.R. \& Caño J.G. (2008) Utilización de recursos de atención primaria por parte de inmigrantes y autóctonos que han contactado con los servicios asistenciales de la ciudad de Lleida. Atención Primaria 40 (5), 225-231.

Standing G. (2011) Labour market policies, poverty and insecurity. International Journal of Social Welfare 20 (3), 260-269.

Tanahashi T. (1978) Health service coverage and its evaluation. Bulletin of the World Health Organization 56 (2), 295-303.

Thomsen T. (2012) Conceptual reflections-transcending the legal aspects of irregular migration. Irregular Migration in a Scandinavian Perspective, pp. 27-47. Shaker Verlag, Maastricht.

Vives A., Vanroelen C., Amable M. et al. (2011) Employment precariousness in Spain: prevalence, social distribution, and population-attributable risk percent of poor mental health. International Journal of Health Services 41 (4), 625-646.

WHO (2010) Health of Migrants: The Way Forward: Report of a Global Consultation. World Health Organization, Madrid, Spain, 3-5 March 2010. 